\title{
The Godfather, Part II
}

\section{Citation}

Roosth, Sophia 2013. The Godfather, Part II. Science 342, no. 6156: 312-313.

\section{Published Version}

doi:10.1126/science. 1243547

\section{Permanent link}

http://nrs.harvard.edu/urn-3:HUL.InstRepos:12575479

\section{Terms of Use}

This article was downloaded from Harvard University's DASH repository, and is made available under the terms and conditions applicable to Open Access Policy Articles, as set forth at http:// nrs.harvard.edu/urn-3:HUL.InstRepos:dash.current.terms-of-use\#OAP

\section{Share Your Story}

The Harvard community has made this article openly available.

Please share how this access benefits you. Submit a story.

\section{Accessibility}




\section{Genomics The Godfather, Part II}

\section{Sophia Roosth}

Life at the Speed of Light From the Double Helix to the Dawn of Digital Life by J. Craig Venter Viking, New York, 2013. 236 pp. \$26.95, C\$28.50. ISBN 9780670025404. Little, Brown, London. £20. ISBN 9781408705247. Paper, £14. ISBN 9781408705254.

The reviewer is at the Department of the History of Science, Harvard University, Science Center \#364, 1 Oxford Street, Cambridge, MA 02138, USA. E-mail: roosth@fas.harvard.edu

Craig Venter is a singular individual who aspires to be universal. In Life at the Speed of Light, he fantasizes this: "since my own genome was sequenced, my software has been broadcast in the form of electromagnetic waves, carrying my genetic information far beyond Earth, as they ripple out into space. Borne upon those waves, my life now moves at the speed of light." He wonders whether an alien civilization might understand and act upon his genome's broadcast "instructions."

No doubt, the Earthbound Venter already wears many hats: scientist (racing the National Institutes of Health to sequence the human genome), sailor (captaining Sorcerer II to sequence the Sargasso Sea), and biotycoon (aggressively commercializing his research). Whereas Venter's previous book ( 1 ) traced his career and personal life, he now offers a 21 st-century response to the question physicist Erwin Schrödinger posed at Trinity College, Dublin, in 1943: "What Is Life?" Seventy years later, Venter strode across the same stage to tackle the same question. Like his predecessor (2), he has produced a book based on his lecture, and he opens by comparing his thinking to Schrödinger's. The book roughly divides into three sections: historical, biographical, and speculative. Venter first looks back to trace the past 60 years of molecular biology, identifying thematic precursors to synthetic biology (e.g., Jacques Loeb's "engineering ideal," Friedrich Wöhler's "proof by synthesis"). Later, he looks ahead to imagine synthetic genomics's future. In between past and prospective, Venter situates himself as a pivot. He is at once inheritor of molecular biology's prior triumphs and the wellspring of its bright future.

The story really gets under way when Venter narrates his involvement in the past 30 years of genomics (although he skims over the Human Genome Project, which he detailed in his earlier book). He compellingly depicts his diverse research as a concerted effort to shuttle biology between the material and digital worlds. Through separate chapters on four key experiments, he describes sequencing the genomes of various bacteria and archaea. Such thinking galvanized Venter's later efforts (starting with synthesizing bacteriophage phi X 174) to move not only from digital to material but also in the other direction. The book is at its best when readers are allowed a glimpse into the J. Craig Venter Institute's (JCVI's) synthesis of Mycoplasma, beginning with synthesizing the $M$. genitalium genome. JCVI scientists next transplanted a $M$. mycoides genome into a recipient $M$. capricolum cell, demonstrating that the cells were induced to grow and divide as M. mycoides cells - a spectacular technical feat.

This project culminated in JCVI's pièce de résistance: sequencing the $M$. mycoides genome, synthesizing and assembling it in a yeast cell, and transplanting it into $M$. capricolum cells to produce "the first living self-replicating species to have a computer as a parent." The memoir's dramatic climax is replete with 4 a.m. text messages; hands shaking with anticipation as they grip incubator doors; and (spoiler alert!) scientists reveling in success, popping bottles of champagne, exchanging birthday balloons, and speaking at clamorous press conferences. This research will be familiar to readers of $S$ cience (in whose pages the results were published). Still, the day-to-day setbacks that plagued researchers as they "booted up" the cell and their thrill at finding a single blue colony on a Petri dish provide a gripping tale and welcome antidote to dry materials and methods sections that make such sagas feel disembodied and inevitable. Throughout, Venter's self-fashioning is careful: He savors his perceived iconoclasm (for example, the first thing future collaborator Ham Smith said to Venter is "I thought you were supposed to have horns"). He believes himself righteous yet embattled, as when his choices to sequence genome fragments and patent expressed sequence tags were met by fellow scientists with reactions ranging from distaste to fury. Venter's "synthetic cell" and the breathless press it garnered-which posed Venter as both god and parent to synthetic life-have been criticized by some who claim the cell isn't truly "synthetic": the genome wasn't designed but sequenced from extant $M$. $m y c o i d e s$. Further, it was inserted into a recipient cell and thus can't be made "from scratch." Venter defends himself against detractors by arguing that such disputes misunderstand what both "synthetic" and "life" mean. He dispenses with his critics by privileging the genome as the definition of life, noting that "creating" "synthetic" "life" affected his thinking about life itself: "Our experiments did not leave much room to support" proponents of "a 'vital force' that [distinguishes] the animate from the inanimate."

And this is Venter's great white whale: Like Schrödinger before him, he has vitalism squarely in his crosshairs. Why, he wonders, has it been resilient enough to survive so many experimental assaults? He bemoans a strain of 21 st-century vitalism that "manifests itself in the guise of shifting emphasis away from DNA to an 'emergent' property of the cell that is somehow greater than the sum of its molecular parts." In his view, any understanding of biology that does not privilege DNA as primum movens-including the sin of "attribut[ing] unmeasurable properties to the cell cytoplasm"-is tantamount to neovitalism. His synthetic cell, in his eyes, hammered the final nail in vitalism's coffin. Not bad for someone in the business of creating life. 
In the book's denouement, Venter imagines futures when biology can shuttle seamlessly between the material and the informatic. Drawing examples from Star Trek and Doctor Who, he speculates that DNA sequencing and synthesis are paired technologies for dematerializing, digitizing, and subsequently rematerializing life. He's confident that soon "we will be able [to] send a robotically controlled genomesequencing unit in a probe to other planets to read the DNA sequence of any alien microbe life that may be there." If such a sequence is beamed back from Mars, "we should be able to reconstruct the genome. The synthetic version of the Martian genome could then be used to recreate Martian life."

Although fantastic, such scenarios proffer one answer to Schrödinger's question. What was life in 1943 , what is it in 2013 , and what will it become next? Despite staggering developments in molecular biology since the 1940s, I'm struck by how little has changed. If Venter is to be believed, life itself has been recreated, yet the same hoary debates are still being aired: mechanism versus vitalism, form versus substance, experimental deduction versus proof by synthesis. Life, it seems, moves more slowly than Venter supposes.

\section{References}

J. C. Venter, A Life Decoded: My Genome: My Life (Viking, New York, 2007).

E. Schrödinger, What Is Life? The Physical A spect of the Living Cell (Cambridge Univ. Press, Cambridge, 1944). 